\title{
Cloning and characterization of a nitrite reductase gene from Alcaligenes faecalis and its expression in Escherichia coli
}

\author{
Makoto Nishiyama, * Junko Suzuki, Mutsuko Kukimoto, Tatsuya Ohnuki, \\ SUEHARU HORINOUCHI and TERUHIKo BEPPU
}

Department of Agricultural Chemistry, Faculty of Agriculture, The University of Tokyo, Yayoi 1-1-1, Bunkyo-ku, Tokyo 113, Japan

(Received 14 September 1992; revised 25 November 1992; accepted 7 December 1992)

\begin{abstract}
The gene (nir) encoding the copper-containing nitrite reductase (NIR) of a denitrifying bacterium, Alcaligenes faecalis S-6, was cloned by a synthetic oligonucleotide-probing method. The nucleotide sequence of the cloned DNA fragment revealed the primary structure of the NIR precursor containing the $\mathrm{N}$-terminal signal sequence for secretion. A nucleotide sequence, possibly recognized by a transcriptional regulator resembling FNR was found upstream of the structural gene. When the cloned gene was expressed in Escherichia coli under the control of the lac promoter at $37^{\circ} \mathrm{C}$, NIR was produced as large inclusion bodies and little activity was detected. When cultivation was at $20^{\circ} \mathrm{C}$, most of the NIR was detected in the soluble fraction and a significant portion of the protein was translocated into the periplasmic space, accompanied by removal of its signal sequence.
\end{abstract}

\section{Introduction}

The denitrifying bacterium Alcaligenes faecalis S-6 possesses an anaerobic nitrate respiration system. A copper-containing nitrite reductase (NIR) catalyses the reduction of $\mathrm{NO}_{2}^{-}$to $\mathrm{NO}$ under anaerobic conditions (Kakutani et al., 1981a, b). Pseudoazurin, a member of the cupredoxin family, also a copper-containing protein composed of 123 amino acids, is required as a direct electron donor for the reduction of $\mathrm{NO}_{2}^{-}$by the enzyme (Kakutani et al., 1981c; Hormel et al., 1986). When reduced pseudoazurin and NIR are incubated under aerobic conditions, however, NIR catalyses the reduction of $\mathrm{O}_{2}$ to $\mathrm{H}_{2} \mathrm{O}_{2}$, which inactivates this enzyme. Thus NIR and pseudoazurin form a unique electron transferring system between two copper-containing proteins. A similar system comprising the copper-containing NIR and pseudoazurin was reported in Achromobacter cycloclastes (Liu et al., 1986).

Crystallographic analyses of pseudoazurin from $A$. faecalis S-6 have revealed a three-dimensional structure

*Author for correspondence. Tel 033812 2111, ext. 5126; fax 03 38120544 .

The sequence data reported in this paper has been submitted to DDBJ, EMBL and GenBank and have been assigned the accession number D13155. consisting of a typical $\beta$-barrel containing a single type I copper atom and two additional $\mathrm{C}$-terminal $\alpha$-helices (Adman et al., 1989; Petratos et al., 1987). The gene encoding pseudoazurin precursor with an N-terminal signal sequence for secretion has been cloned and expressed in Escherichia coli, allowing production of correctly processed pseudoazurin in the periplasmic space (Yamamoto et al., 1987). This expression system, with site-directed mutagenesis, has generated several mutant proteins. One of these mutants, with Pro- 80 replaced by Ala at the position adjacent to two copper ligands, Cys-78 and His-81, shows a marked increase in the redox potential but no change in affinity for NIR (Nishiyama et al., 1992). Further characterization of the interaction between pseudoazurin and NIR, requires information on NIR structure and function. NIR from A. faecalis $\mathrm{S}-6$ has been crystallized and preliminary Xray analysis done (Petratos et al., 1986). Recent crystallographic analysis of $A$ ch. cycloclastes NIR revealed a trimeric structure composed of three identical subunits and six copper atoms (Godden et al., 1991). In this paper, we describe the cloning and nucleotide sequence of the nir gene from $A$. faecalis S-6 and its expression in $E$. coli. These results provide a base for site-directed mutagenesis of NIR and for a better understanding of the mechanism of electron transfer between the coppercontaining proteins. 


\section{Methods}

Enzymes and chemicals. Restriction endonucleases, T4 DNA ligase, T4 polynucleotide kinase and pyroglutamate aminopeptidase were purchased from Takara Shuzo. $\left[\alpha-{ }^{32} \mathrm{P}\right] \mathrm{dCTP}$ and $\left[\gamma-{ }^{32} \mathrm{P}\right] \mathrm{ATP}$ were from Amersham Japan. A kit for nucleotide sequencing by the M13dideoxynucleotide method was obtained from United States Biochemicals. Oligonucleotides were synthesized by a Cyclone Plus DNA synthesizer (Milligen/Biosearch).

Bacterial strains and plasmids. A. faecalis S-6 (Kakutani et al., 1981 a) was used as the source for NIR and used as the DNA donor. E. coli JM105 [ $\Delta$ (lac-pro) thi strA endA sbc-15 hsdR4 $\mathrm{F}^{\prime}$ traD36 proAB lac ${ }^{\mathrm{q}}$ lacZ $\triangle M 15]$ was used as a host for cloning and expression of the nir gene from $A$. faecalis S-6 and was used for M13 phage propagation. pUC19 (Yanisch-Perron et al., 1985) was used for cloning and the expression of the nir gene. pNIR201 is a plasmid, obtained in this study, which contains the nir gene in a $2.4 \mathrm{~kb}$ PstI fragment cloned in pUC19. pNIR501 is a plasmid which allows expression of the nir gene under the control of the lac promoter. It was constructed as follows. To introduce the HindIII site just upstream of the putative ribosomebinding site of the nir gene, polymerase chain reactions were carried out using synthetic oligonucleotides 5'CAAGCTTGTAAAGGAGAGTATCGATGGCC 3 ', which corresponded to the translational initiation region, and 5'CATGAATTCGACCACCTTGGG3' including an EcoRI site within the coding sequence (see Fig. 2). Thermal cycling $\left(94^{\circ} \mathrm{C}\right.$ for $1 \mathrm{~min}, 50^{\circ} \mathrm{C}$ for $1 \mathrm{~min}$, and $72^{\circ} \mathrm{C}$ for $1 \mathrm{~min}$ ) was repeated 20 times. After digestion of the amplified DNA with HindIII and EcoRI, the resulting restriction fragment of about $250 \mathrm{bp}$ and a $1.5 \mathrm{~kb}$ EcoRI-PstI fragment from pNIR201 were ligated with pUC19 digested with HindIII and PstI to produce pNIR501.

Gene manipulation. Total chromosomal DNA of $A$. faecalis was prepared by the method of Saito \& Miura (1963). For cloning the nir gene, three oligonucleotides (probe 1, TAQGAQAAPATQTAQTAQGT; probe 2, GAPCAPGAQTTQTAQGT; probe 3, AAPTAQAAPAAPTAQGAPGC; $P$ and $Q$ represent $G+A$ and $C+T$, respectively) were synthesized based on the partial amino acid sequences of NIR and were used as the probes for Southern hybridization (Southern, 1975) with the modifications as follows. Hybridization in $6 \times \mathrm{NET}(0.9 \mathrm{M}-\mathrm{NaCl}, 90 \mathrm{~mm}-\mathrm{Tris} / \mathrm{HCl} ; \mathrm{pH} 7.5$, 6 mM-EDTA) containing $0.5 \%$ Nonidet P-40 was carried out at room temperature for $8-10 \mathrm{~h}$ and non-hybridized probes were washed out with $4 \times \mathrm{SSC}$ at an appropriate temperature $(1 \times \mathrm{SSC}$ is $0 \cdot 15 \mathrm{M}-\mathrm{NaCl}$, $0.015 \mathrm{M}$-trisodium citrate, $\mathrm{pH} 7.0$ ). Colony hybridization was carried out according to Grunstein \& Hogness (1975) under the same hybridization conditions described above. Nucleotide sequencing was done by the dideoxy chain-termination method using M13 phages (Messing, 1983; Sanger et al., 1977). All the restriction sites used for cloning on M13 RFI DNA were verified by determination of part of an overlapping sequence.

Purification of NIR from A. faecalis S-6. A. faecalis S-6 was precultured in $10 \mathrm{ml} \mathrm{L}$-broth (Maniatis et al., 1982) aerobically at $30^{\circ} \mathrm{C}$ for $15 \mathrm{~h}$. The cells were then transferred to 11 NABN medium containing $0.7 \mathrm{~g} \mathrm{~K}_{2} \mathrm{HPO}_{4}, 0.3 \mathrm{~g} \mathrm{KH}_{2} \mathrm{PO}_{4}, 5 \mathrm{~g} \mathrm{KNO}_{3}, 10 \mathrm{~g}$ bouillon (Kyokuto, Tokyo), $1 \mathrm{~g}$ yeast extract (Difco), $10 \mathrm{~g} \mathrm{CH}_{3} \mathrm{COONa} .3 \mathrm{H}_{2} \mathrm{O}$, $100 \mathrm{mg} \mathrm{MgSO}{ }_{4} \cdot 7 \mathrm{H}_{2} \mathrm{O}, 20 \mathrm{mg} \mathrm{CaCl} 2.2 \mathrm{H}_{2} \mathrm{O}, 2 \mathrm{mg} \mathrm{MnCl} 2.4 \mathrm{H}_{2} \mathrm{O}, 1 \mathrm{mg}$ $\mathrm{NaMoO}_{4} \cdot 2 \mathrm{H}_{2} \mathrm{O}, 1 \mathrm{mg} \mathrm{CuSO} \mathrm{m}_{4} .5 \mathrm{H}_{2} \mathrm{O}$, and $1 \mathrm{mg} \mathrm{FeCl} \mathrm{me}_{3} .6 \mathrm{H}_{2} \mathrm{O}$, pH $6 \cdot 8$, and were cultured anaerobically at $30^{\circ} \mathrm{C}$ for $48 \mathrm{~h}$. The cells were harvested by centrifugation, suspended in $60 \mathrm{ml} 20 \mathrm{~mm}$-potassium phosphate buffer (pH 6.2) containing 1 mM-PMSF (buffer A), and disrupted by ultrasonication (Branson Sonifier; cell disrupter model 200). After removal of the insoluble materials by centrifugation at $50000 \mathrm{~g}$ for $1 \mathrm{~h}, 25 \mathrm{~g}$ ammonium sulphate was added to the supernatant (about $60 \%$ saturation). The mixture was stored at $4{ }^{\circ} \mathrm{C}$ overnight. The precipitate, which was collected by centrifugation at $3000 \mathrm{~g}$ for $30 \mathrm{~min}$, was dissolved in $5 \mathrm{ml}$ water and dialysed against water overnight. After dialysis against $20 \mathrm{~mm}$-potassium phosphate

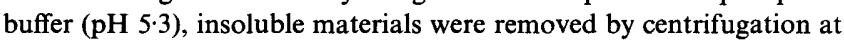
$10000 \mathrm{~g}$ for $20 \mathrm{~min}$. The supernatant was dialysed against buffer $\mathrm{A}$ and the dialysate was applied to a DEAE-Toyopearl column $(4.5 \times 50 \mathrm{~cm}$; Tosoh, Tokyo). The adsorbed proteins were eluted with buffer $\mathrm{A}$ containing $300 \mathrm{~mm}-\mathrm{KCl}$ and again dialysed against the same buffer. The solution prepared in this way was applied to FPLC equipped with a MonoQ anion-exchanger column $(5 \times 50 \mathrm{~mm}$; Pharmacia $)$ and eluted with a linear gradient of $\mathrm{KCl}(150-300 \mathrm{~mm})$ in buffer A. The active fractions eluting at about $220 \mathrm{mM}-\mathrm{KCl}$ were collected and concentrated by using a Centricon 30 filter (Amicon). The concentrated preparation was then applied to FPLC equipped with a Superose 12 gel filtration column $(1 \times 30 \mathrm{~cm}$; Pharmacia $)$ and active fractions were collected. The sample was applied once again to MonoQ FPLC in the same way, and the eluted active fractions were used as the purified preparation.

Amino acid sequencing of NIR. Cleavage of NIR with $\mathrm{CNBr}$ and isolation of the generated peptides were carried out as follows. The purified NIR $(2 \mathrm{nmol})$ dissolved in $1 \mathrm{ml}$ water was dialysed against $500 \mathrm{ml}$ of $70 \%(\mathrm{v} / \mathrm{v})$ formic acid. One milligram $\mathrm{CNBr}$ was added to the dialysate $(1 \mathrm{ml})$ and incubated for $24 \mathrm{~h}$. The mixture was then diluted with 9 vols water and lyophilized. The lyophilized sample, which was dissolved in $25 \mu \mathrm{l}$ water containing $5 \%$ acetonitrile, was subjected to HPLC (Shimadzu, LC-4A, Kyoto) using an ODS-304-1251 reverse-phase column $(4.6 \times 250 \mathrm{~mm}$; Senshu Chemicals, Tokyo). Elution with a linear gradient of acetonitrile (5-95\%) gave more than five peptide peaks, of which the largest was collected and purified by rechromatography on the same column. This purified $\mathrm{CNBr}$-cleaved peptide fragment was subjected to automated Edman degradation (Applied Biosystems, model 473A). For determination of the Nterminal amino acid sequence, 700 pmol NIR was applied to SDSPAGE (Laemmli, 1970) and the proteins were electroblotted onto polyvinylidene difluoride membrane (Immobilon, Millipore) with a blotting apparatus (Sartorius, Sartoblot II-S). NIR proteins blotted onto the membrane were stained with amidoblack and each protein band was collected separately by cutting the sheets. After being washed with water, the sheets were subjected directly to automated Edman degradation. Similar analysis was carried out with the NIR preparation treated with 2.5 milliunits of pyroglutamate aminopeptidase in $50 \mu \mathrm{l}$ $25 \mathrm{~mm}$-potassium phosphate buffer (pH 7.0) containing $10 \mathrm{mM}$-DTT at $37^{\circ} \mathrm{C}$ for $8 \mathrm{~h}$.

Preparation of anti-NIR antiserum. The purified NIR preparation $(0.1 \mathrm{mg})$ dissolved in $0.5 \mathrm{ml}$ distilled water was mixed and homogenized with an equal volume of complete Freund's adjuvant and injected into a young male rabbit $(2 \mathrm{~kg})$ at multiple sites on the back. Two weeks later, a booster of $0.1 \mathrm{mg}$ NIR was injected in the same way. After an additional two weeks, whole blood was collected. About $30 \mathrm{ml}$ antiNIR antiserum was obtained by centrifugation at $1500 \mathrm{~g}$ for $15 \mathrm{~min}$. Western blotting with this antiserum was carried out by the method of Burnett (1981).

Expression of nir gene in E. coli. E. coli cells carrying pNIR501 were precultured in $10 \mathrm{ml} 2 \times$ YT medium (Yanisch-Perron et al., 1985) containing $50 \mu \mathrm{g}$ ampicillin $\mathrm{ml}^{-1}$ at $30^{\circ} \mathrm{C}$ for $12 \mathrm{~h}$. A portion $(0.1 \mathrm{ml})$ of the preculture was transferred to $10 \mathrm{ml}$ of the same medium and cultured aerobically for $4 \mathrm{~h}$ at $37^{\circ} \mathrm{C}, 26.5^{\circ} \mathrm{C}$, and $20^{\circ} \mathrm{C}$. Isopropyl- $\beta$-Dthiogalactopyranoside (IPTG) and $\mathrm{CuSO}_{4} .5 \mathrm{H}_{2} \mathrm{O}$ were then added to give concentrations of $1 \mathrm{mM}$ and $100 \mu \mathrm{M}$, respectively, and cultivation was continued for $10 \mathrm{~h}$ more. The cells were harvested, suspended in $0.5 \mathrm{ml} 10 \mathrm{~mm}$-Tris/HCl $(\mathrm{pH} 7.5)$, and disrupted by sonication. NIR activity was determined according to Kakutani et al. $(1981 \mathrm{~b})$ and one unit of the enzyme activity was defined as the amount of enzyme which catalysed the reduction of $1 \mu \mathrm{mol} \mathrm{NO}-\mathrm{min}^{-1}$. Proteins were determined 


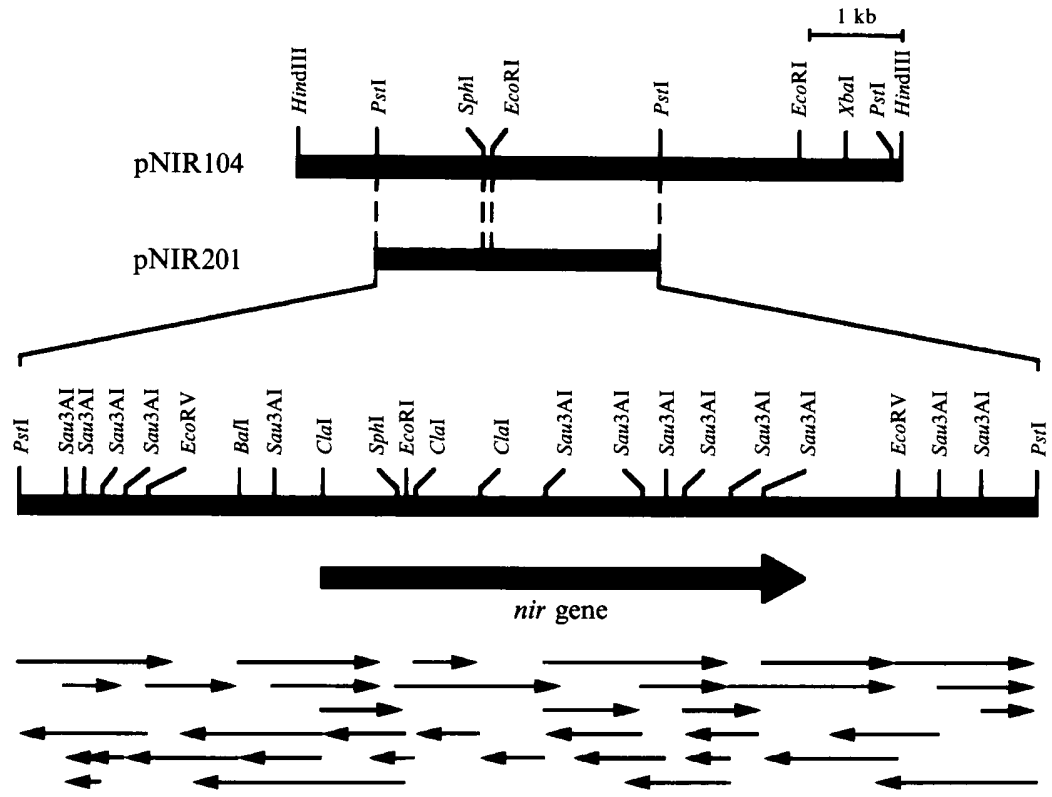

Fig. 1. Restriction maps of pNIR104 and pNIR201 containing the nir gene from $A$. faecalis, with sequencing strategy. pNIR104 contains a $5.0 \mathrm{~kb}$ HindIII fragment at the HindIII site of pUC19, and pNIR201 carries a $2.4 \mathrm{~kb} P s t \mathrm{I}$ fragment at the PstI site.

by the method of Bradford (1976). Cell fractionation of $E$. coli cells was performed according to the method of Cornelis (1982).

\section{Results}

\section{Purification of NIR and determination of its partial} amino acid sequences

Although we tried to purify the NIR from $A$. faecalis to homogeneity, the final preparation still showed two or three protein bands with molecular sizes from 36 to $37 \mathrm{kDa}$ on SDS-PAGE. When the NIR preparation containing apparently three components was subjected to the automated amino acid sequencing, two major phenylhydantoinyl-amino acid signals were obtained in the ratio $2: 1$. From this result, two $\mathrm{N}$-terminal amino acid sequences, KATAAE and AEIAAL, were determined. In addition, this sequencing analysis suggested the presence of a minor component with the N-terminal sequence RKATAA. When the same NIR preparation was treated with pyroglutamate aminopeptidase and was then subjected to the automated amino acid sequencing, another sequence, GAVRKA, was obtained together with the three amino acid sequences described above. Considering the nucleotide sequence of the nir gene determined as described below, we assume that the $\mathrm{N}$ terminal amino acid of the intact NIR from $A$. faecalis is pyroglutamate and that the $\mathrm{N}$-terminal part is processed by a protease to produce the observed heterogeneity.

We also cleaved the NIR preparation with $\mathrm{CNBr}$ and isolated a single peak by HPLC. The amino acid sequencing analysis of this peptide fragment gave an internal amino acid sequence with 49 amino acids: VLPREGLHDGKGKALTYDKIYYGEQDFYVPRD ENGKYKKYEAPGDAYE.

\section{Cloning and sequencing of the nir gene}

For cloning of the nir gene from A. faecalis, three oligonucleotide probes were synthesized according to the amino acid sequence of the internal peptide fragment. When chromosomal DNA from $A$. faecalis digested with HindIII or PstI was Southern-blotted with the ${ }^{32} \mathrm{P}$ labelled oligonucleotides, two restriction fragments of about $5.0 \mathrm{~kb}$ and $2.4 \mathrm{~kb}$ showed positive hybridization with probe 3 . Each restriction fragment was purified from the agarose gel, ligated with pUC19 digested with HindIII or PstI, and introduced into E. coli. Screening of several hundred transformants by the method of colony hybridization with probe 3 yielded a single positive colony containing a plasmid with a $5.0 \mathrm{~kb}$ HindIII insert and two positive colonies carrying a plasmid with a $2.4 \mathrm{~kb}$ Pst I insert in the same orientation. The plasmid containing the $5.0 \mathrm{~kb} H$ indIII fragment was designated pNIR 104 and the plasmid containing the $2.4 \mathrm{~kb}$ PstI fragment was named pNIR201 (Fig. 1).

The nucleotide sequence of the $2.4 \mathrm{~kb}$ Pst I fragment was as shown in Fig. 2. A single ORF which starts at ATG (nucleotide 751) and terminates at TAA (nucleotide 1879) was found. This ORF encodes a protein of 376 amino acids including the amino acid sequences identical to those determined by the Edman degradation. At its $\mathrm{N}$ terminus, an amino acid sequence with two arginine residues followed by hydrophobic amino acids was present, which is a feature typical of the signal peptide in 


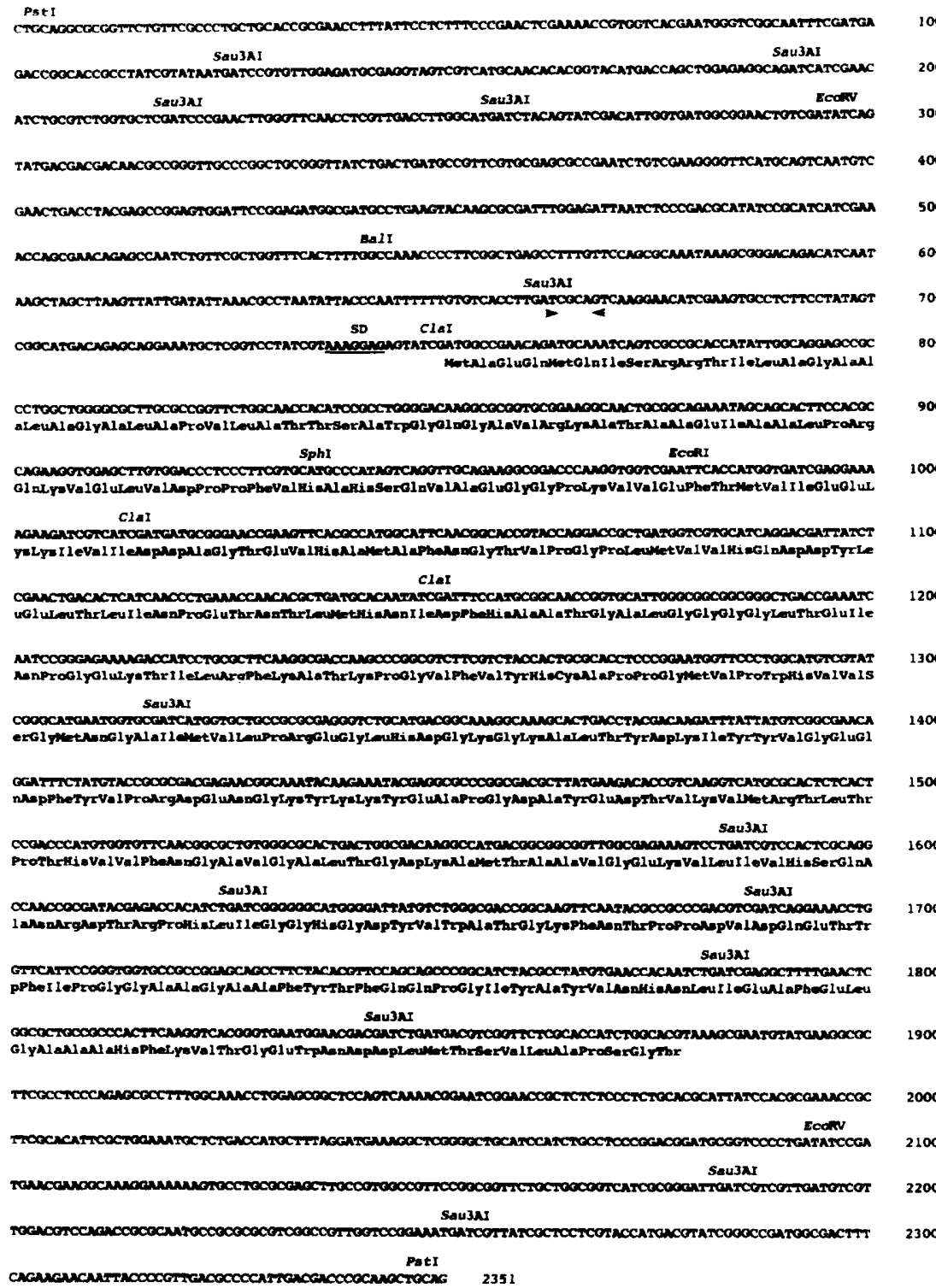

Fig. 2. Nucleotide and deduced amino acid sequences of the nir gene of $A$. faecalis. A potential ribosome-binding site is marked as SD. Facing arrows indicate a putative FNR binding sequence. secreted proteins (Inouye et al., 1977). By amino acid sequencing analyses with the NIR mixtures, four Nterminal amino acid sequences had been obtained as described above. These sequences were found to start from Gln-34, Arg-38, Lys-39, and Ala-43 in the deduced sequence. By analogy with the signal sequences of other secreted proteins, we concluded that the peptide from Met-1 to Gly-33 serves as the signal sequence for secretion and that the $\mathrm{N}$-terminal Gln-34 in the mature NIR is converted to pyroglutamate in $A$. faecalis. Three other N-terminal amino acid sequences presumably resulted from nonspecific proteolysis by an aminopeptidase present in $A$. faecalis.

Recently, Fenderson et al. (1991) chemically determined the primary structure of a similar coppercontaining NIR from Achromobacter cycloclastes which also requires a small copper-containing cupredoxin as an acceptor/donor of proton for the enzyme reaction. When the deduced amino acid sequence of the NIR from A. faecalis was compared with that from Ach. cycloclastes, $81 \%$ identity was observed (Fig. 3), which is higher than the amino acid identity $(65 \%)$ observed between the cupredoxins from these organisms (Ambler, 1977).

A nucleotide sequence similar to that recognized by the transcription factor FNR, which controls the expression of various genes involved in the anaerobic metabolism of E. coli (Spiro \& Guest, 1990), is found approximately $85 \mathrm{bp}$ upstream of the putative translational initiation codon of the nir gene. A similar FNRlike sequence was also found upstream of the pseudoazurin structural gene of this bacterium (Fig. 4). 


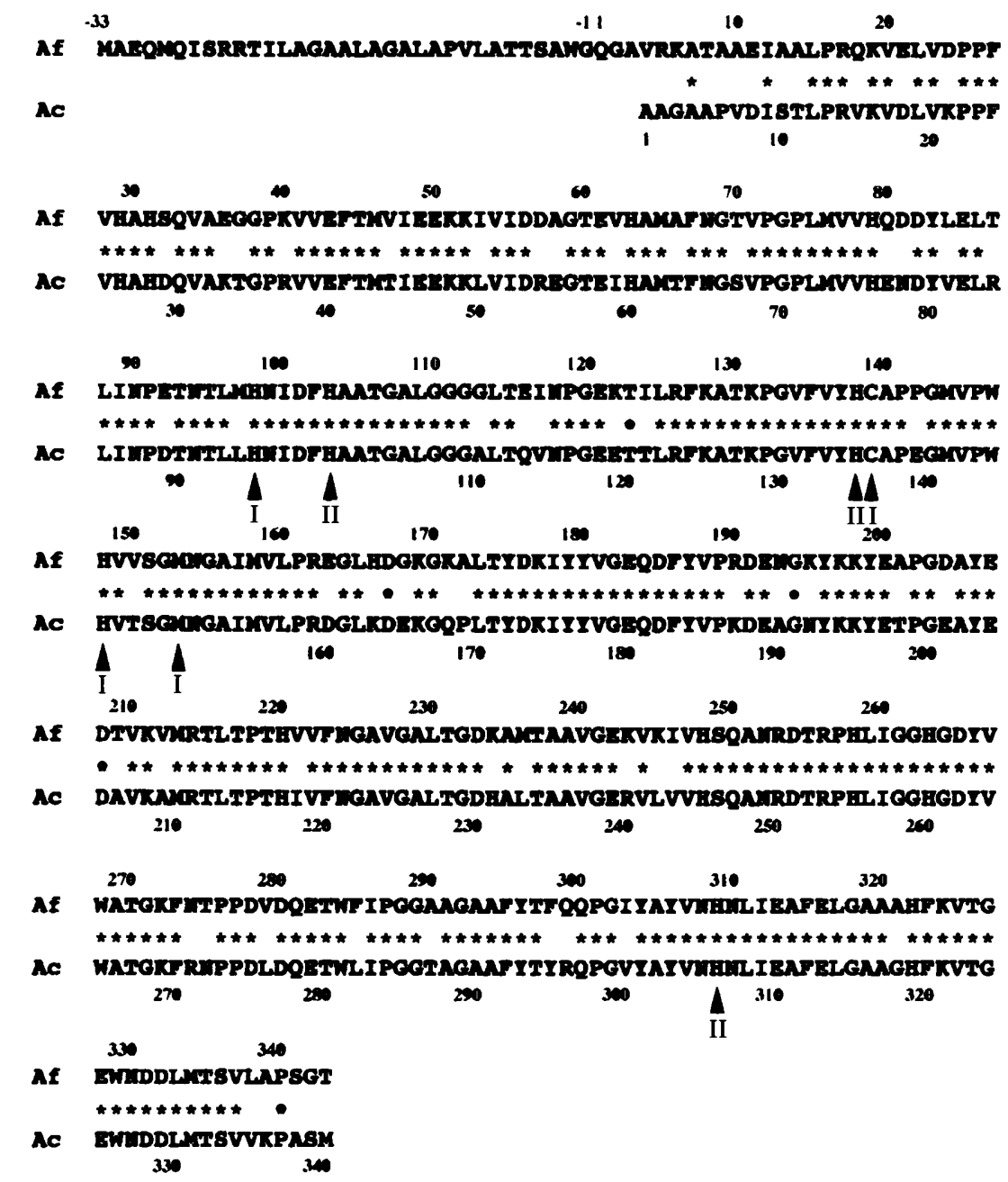

Fig. 3. Comparison of amino acid sequences of NIRs. Identical amino acids are marked with asterisks (*). Ac, NIR of Ach. cycloclastes; Af, NIR from $A$. faecalis. The ligands for type I and type II copper atoms of the NIR from Ach. cycloclastes are indicated as I and II, respectively.

\section{Expression of the nir gene in E. coli}

To express the nir gene in $E$. coli, we constructed a plasmid, pNIR501, in which the nir gene including the Shine-Dalgarno sequence (Fig. 2) was located just downstream of the lac promoter. When E. coli transformants harbouring pNIR501 were cultured at $37^{\circ} \mathrm{C}$, the formation of inclusion bodies was observed irrespective of the presence or absence of IPTG (data not shown). The cell extracts were then analysed by SDSPAGE and by Western blotting with antibody raised against NIR purified from $A$. faecalis. A large amount of the protein cross-reactive to the anti-NIR antibody was detected in the cells grown in both the presence and absence of IPTG. Its molecular mass ( $43 \mathrm{kDa})$ is close to that calculated from the deduced sequence of preNIR protein with the signal sequence $(41 \mathrm{kDa})$. Fractionation of the cell extract revealed that the protein was localized mainly (more than 95\%) in the insoluble fraction (Fig. 5). In accordance with this observation, very little NIR activity $\left[0.19 \mathrm{U}(\mathrm{mg} \text { protein })^{-1}\right]$ was detected in the supernatant fraction of the cell extract (Table 1) and almost no activity in the insoluble fraction (data not shown). N-terminal sequencing of NIR in the insoluble fraction showed the sequence AEQMQIS, which corresponds to the $\mathrm{N}$-terminal portion of the deduced amino acid sequence, lacking the first methionine residue at the $\mathrm{N}$-terminus of the signal sequence.

We next examined a possible effect of lowering the cultivation temperature on the formation of inclusion bodies. When the same $E$. coli transformants were grown at $26.5^{\circ} \mathrm{C}$, the protein cross-reactive to the antibody was detected in the soluble fraction almost exclusively. Expression of the nir gene at $26.5^{\circ} \mathrm{C}$ also depended on the presence of IPTG. NIR activity in the supernatant fraction of the crude cell extract of the $E$. coli transformant grown at $26.5^{\circ} \mathrm{C}$ was $3.62 \mathrm{U}$ (mg protein) $)^{-1}$, which was 20 times higher than that from the cells grown at $37^{\circ} \mathrm{C}$ (Table 1). The specific activity obtained from the $E$. coli transformant was approximately half that $[6.5 \mathrm{U}$ (mg protein) ${ }^{-1}$ ] from $A$. faecalis. Although SDS-PAGE showed the presence of multiple cross-reactive proteins 
paz

nir

$\operatorname{frd} A E c$

frdA $P v$

$g \operatorname{lp} A$

dms $A$

narG

nir $B$

\begin{abstract}
TAACTTCACCTGITTGATCCAGATCAPAGAGTTGGCAGGCGACAGGTCTAAACCCCGTTACGTGGCGTG TTTTTGTGTCACQITGAICGCAGICASGGAACATCGAAGTGCCTCTTCCTATAGTCGGCATGACACAGCA GCGCACTAAAAAA I CGATCTCGICAA ATTTCAGACTTATCCATCAGACTATACTGTTGTACCTATAAAG ATACGGGAAACCA IOATIPCATATCAA ATTTCCGTACCTTACATTTCGTTATACTAAAATTACAGTCAAT AATGTTCAAAATGACECATGAATCACGTTTCACTTTCGAATTATGAGCGAATATGCGCGAAATCAAACA TTTTTGTCTCCCIITGAT CCE CAATAATTACTCCTCACTTACACGTAAATACTACTITCGAGTGAAA CCCATCATCACTCTTGATCGTUATCAA TTCCCACGCTGTTTCAGAGCGTTACCTTECCCTTAAACATTA TATAAAGGTGAAI[TGATITTACATCAATAAGCGGGTTGCTGAATCGTTMAGTAGGCGTAATAGAAAA
\end{abstract}

TrGat----ATcax

FNR consensus sequence
-10 region

Fig. 4. Alignment of FNR-binding sequences. Abbreviations: paz, pseudoazurin gene of A. faecalis; nir, nir gene of $A$. faecalis; frdA $E c$, frdA gene encoding fumarate reductase of $E$. coli; frdA Pv, frdA gene encoding fumarate reductase of Proteus vulgaris; glpA, glpA gene encoding glycerol-3-phosphate dehydrogenase of $E$. coli; $d m s A, d m s A$ gene encoding dimethylsulphoxide reductase of $E$. coli; nar $G$, narG gene encoding nitrate reductase of $E$. coli; and $\operatorname{nir} B, \operatorname{nir} B$ gene coding for nitrite reductase of $E$. coli. Nucleotide sequence and transcription mapping data are from: paz (Yamamoto et al., 1987); frdA Ec (Eiglmeier et al., 1989); frdA Pv (Eiglmeier et al., 1989); glpA (Eiglmeier et al., 1989); dms A (Eiglmeier et al., 1989); narG (Li \& DeMoss, 1987), and nirB (Jayaraman et al., 1988). FNR-binding sequences are boxed. Bold letters represent -10 regions of these genes. Transcriptional start points are underlined.

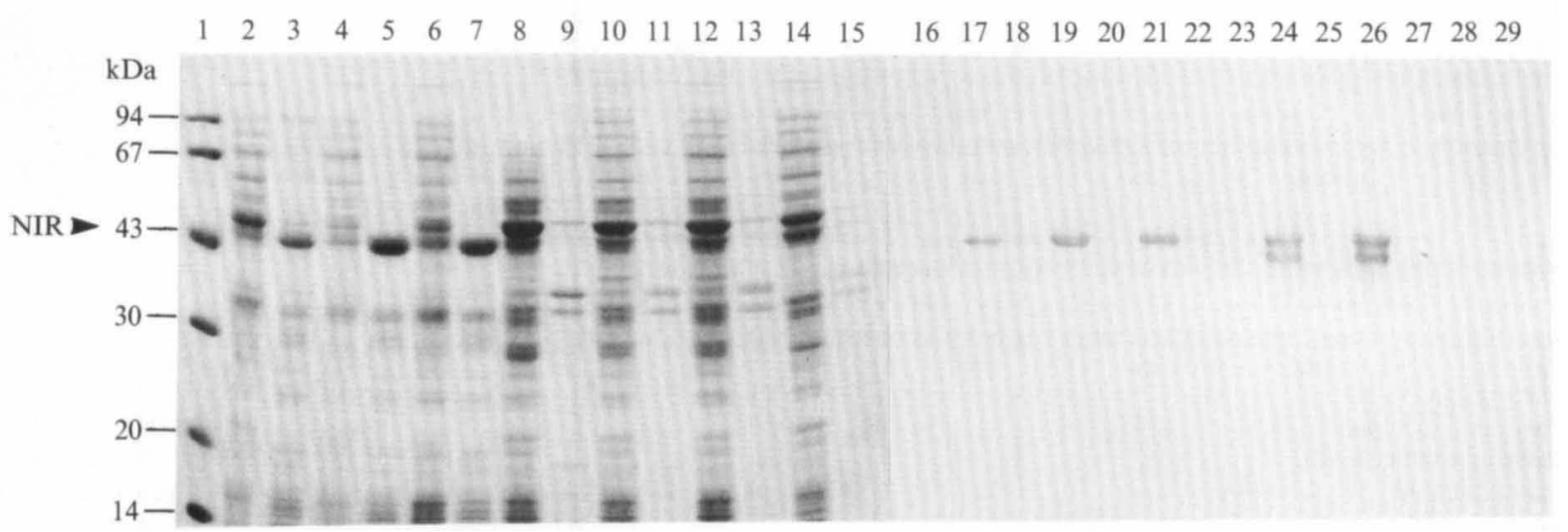

Fig. 5. SDS-PAGE and Western blotting with anti-NIR serum. SDS-PAGE (lanes 1-15), Western blotting with antiserum raised against NIR (lanes 16-29). Molecular markers (lane 1), crude extract prepared from E. coli JM105(pNIR501) cultured at $37^{\circ} \mathrm{C}$ (lanes 2, 3, 16 and 17), that from E. coli JM105(pNIR501) grown in the presence of $1 \mathrm{mM}$-IPTG at $37^{\circ} \mathrm{C}$ (lanes $4,5,18$ and 19), that from E. coli JM105(pNIR501) grown in the presence of $1 \mathrm{mM}-\mathrm{IPTG}$ and $100 \mu \mathrm{M}-\mathrm{CuSO}_{4}$ at $37^{\circ} \mathrm{C}$ (lanes $6,7,20$ and 21 ), that from $E$. coli JM105(pNIR501) grown at $26.5^{\circ} \mathrm{C}$ (lanes 8, 9, 22 and 23), that from E. coli JM105(pNIR501) cultured in the presence of 1 mM-IPTG at $26.5^{\circ} \mathrm{C}$ (lanes $10,11,24$ and 25), that from E. coli JM105(pNIR501) cultured in the presence of $1 \mathrm{mM}-\mathrm{IPTG}$ and $100 \mu \mathrm{M}^{-\mathrm{CuSO}}{ }_{4}$ at $26.5^{\circ} \mathrm{C}$ (lanes $12,13,26$ and 27), and from E. coli JM105 grown at $37^{\circ} \mathrm{C}$ (lanes $14,15,28$ and 29). Supernatants of the crude extracts, lanes $2,4,6,8,10,12,14,16,18,20,22,24,26$ and 28 , precipitates of the crude extracts, lanes $3,5,7,9,11,13,15,17,19,21,23,25$, 27 and 29.

Table 1. Effect of cultivation temperature on NIR production by E. coli JM105 harbouring pNIR501

\begin{tabular}{lcc}
\hline \hline Plasmid & $\begin{array}{c}\text { Cultivation temp. } \\
\left({ }^{\circ} \mathrm{C}\right)\end{array}$ & $\begin{array}{c}\text { Specific NIR activity* } \\
{[\text { units (mg protein) })^{-1}}\end{array}$ \\
\hline None & 26.5 & 0.01 \\
pNIR501 & 26.5 & 3.62 \\
pNIR501 & 37.0 & 0.19 \\
\hline
\end{tabular}

\footnotetext{
* Specific activity in the supernatant fraction obtained by cen-
} trifugation of the cell lysate.

with very similar molecular masses, the largest component had a molecular mass almost identical to that of the NIR produced as inclusion bodies at $37^{\circ} \mathrm{C}$. When cells were cultivated at $20^{\circ} \mathrm{C}$, the cross-reactive proteins were detected not only in the cytoplasmic but also in the periplasmic fraction (Fig. 6). The molecular mass of the NIR protein in the periplasmic space was $37 \mathrm{kDa}$, which is identical to that of the mature NIR purified from $A$. faecalis. These results, suggest that a significant portion of the NIR produced at lower temperatures was translocated into the periplasmic space after processing of the signal sequence. We also examined the effect of copper in the culture medium on the NIR production at $26.5^{\circ} \mathrm{C}$, because copper was required for the efficient production of pseudoazurin in E. coli (Nishiyama et al., 1992). However, no effect was observed at $37^{\circ} \mathrm{C}$ or $26.5{ }^{\circ} \mathrm{C}$ (Fig. 5). 


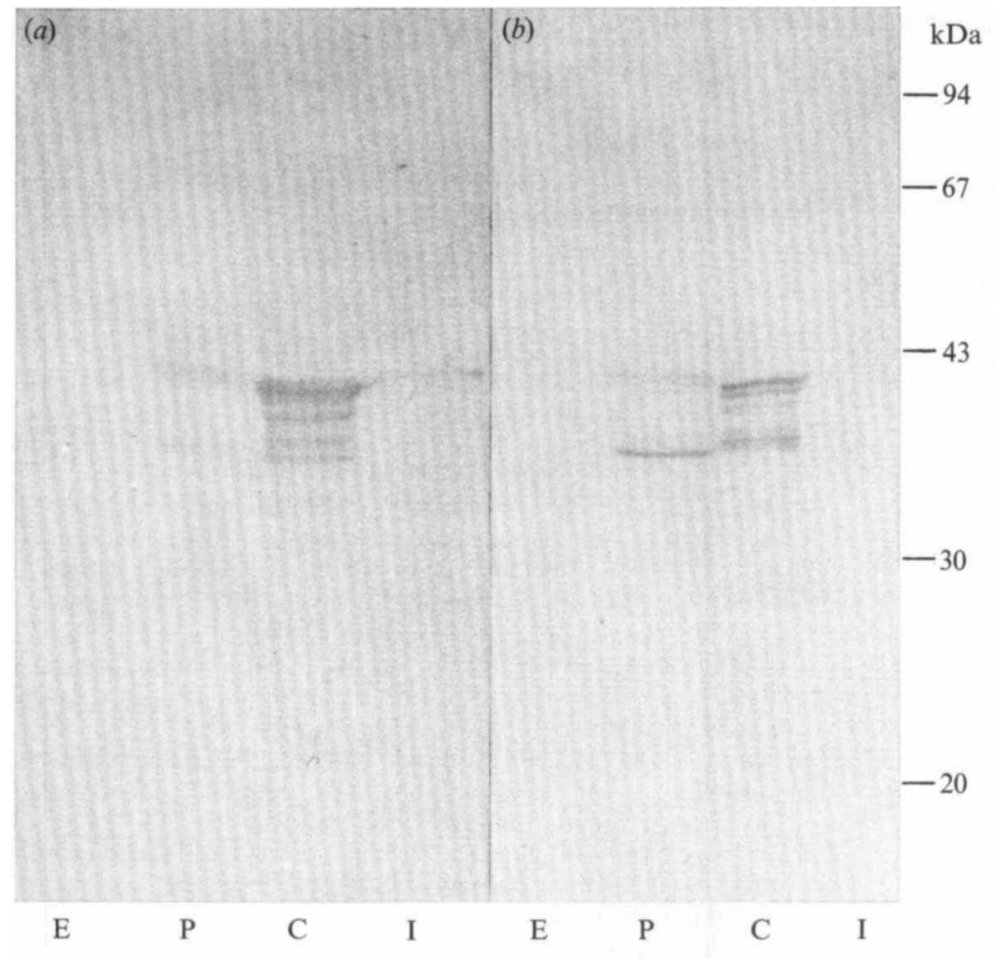

Fig. 6. Effect of temperature on localization of the NIR in $E$. coli cells carrying pNIR501, analysed by Western blotting with anti-NIR serum. After removal of the culture medium as extracellular fraction $(\mathrm{E})$, the cells were fractionated into periplasmic (P), cytoplasmic (C), and insoluble (I) fractions. (a), E. coli JM105(pNIR501) cultured at $26.5^{\circ} \mathrm{C} ;($ b), E. coli JM105(pNIR501) cultured at $20^{\circ} \mathrm{C}$.

\section{Discussion}

Cloning and sequencing of the nir gene revealed the deduced amino acid sequence of a subunit. NIR from Achromobacter cycloclastes was recently crystallized and its three dimensional structure has been already determined by X-ray crystallographic analysis at $2 \cdot 3 \AA$ resolution (Godden et al., 1991). This analysis revealed that Ach. cycloclastes NIR is a trimer composed of three identical subunits. Three type I copper atoms occur in the complex (one in each subunit) while three type II copper atoms are bound in the spaces between the subunits. The significant identity in the sequence strongly suggests that NIR of $A$. faecalis also takes a similar trimeric form. We previously reported that $A$. faecalis NIR was a $110 \mathrm{kDa}$ protein containing $4.5 \mathrm{~mol}$ copper atoms per mol enzyme (Kakutani, et al., 1981 b). In that work, we also estimated the molecular mass of a monomer to be $30 \mathrm{kDa}$. According to these values, we concluded that the NIR of $A$. faecalis consists of four identical subunits, each of which contains a single copper atom. However, it seems obvious from the present study that the former conclusion was wrong due to low estimates of both the copper contents and the subunit size. We here conclude that the NIR of $A$. faecalis is also composed of three identical subunits containing two copper atoms per monomer. In the Ach. cycloclastes NIR, four amino acid residues (His-95, Cys-136, His-145, and Met-150) serve as the ligands for the type I copper with a distorted tetrahedral arrangement and three histidines, His-100, His-135, and His-306, and a water molecule are associated with the type II copper atom with a regular tetrahedral arrangement. All these residues are conserved in the sequence of the NIR of $A$. faecalis (Fig. 3). These residues are good candidates for sitedirected mutagenesis studies to elucidate the mechanism of the catalytic reaction and of electron-transfer in copper-containing NIRs.

Although the expression plasmid pNIR501 was constructed to express the nir gene under the control of the lac promoter, large amounts of the NIR proteins were produced at $37^{\circ} \mathrm{C}$ even in the absence of IPTG. We assume that the LacI repressor could recognize the operator sequence only at the lower affinity when the 5 flanking region of the nir gene was located just downstream of it, and that the repressor protein may be partially inactivated at the higher temperature during a somewhat long period of cultivation $(10 \mathrm{~h})$. The derepressed expression of the nir gene at the higher temperature may result from the combination of these two factors.

When the nir gene was expressed at $37^{\circ} \mathrm{C}$, the NIR protein was produced in the cell as enzymically inactive inclusion bodies. But at $26.5^{\circ} \mathrm{C}$, the protein was produced in soluble forms in the cytoplasmic fraction. Furthermore, at $20^{\circ} \mathrm{C}$ NIR was partially secreted into the periplasmic space. It has been reported that human interferon- $\alpha 2$, which forms inclusion bodies in E. coli at 
$37^{\circ} \mathrm{C}$, took a soluble form when the cells were grown at a lower temperature (Schein \& Noteborn, 1988) and that the processing of subtilisin E of Bacillus subtilis fused to the $E$. coli OmpA signal peptide was greatly affected by the growth temperature during its secretion into the periplasm of E. coli (Ikemura et al., 1987). These results support the idea that a lower rate of protein synthesis at a lower temperature may allow the NIR protein to be folded correctly in the cytoplasm and may facilitate the secretion to the periplasmic space.

The FNR protein is a transcription factor for a number of genes expressed only during anaerobic growth of $E$. coli cells (Spiro \& Guest, 1990). In the genes positively regulated by FNR, the FNR-binding sequences are present about 25 bp upstream of the -10 consensus sequence, while the -35 consensus sequence is not found (Fig. 4). Such a feature is also found in the nir gene (TATAGT with $22 \mathrm{bp}$ spacing to the putative FNR-binding site) (see Fig. 4). This is also true for the pseudoazurin gene of this organism (TTACGT with 31 bp spacing), which encodes the electron donor to NIR (Yamamoto et al., 1987).

Since FNR is detected at the same concentration in the cells during either aerobic or anaerobic growth (Unden $\&$ Guest, 1985), this protein is assumed to take an active form only in the absence of oxygen to bind a specific sequence in the promoters of FNR-dependent genes. Our previous work revealed the necessity of anaerobic growth for the efficient production of both NIR and pseudoazurin in A. faecalis (Kakutani et al., 1981a). We may assume that the FNR-like sequences located upstream of the nir and pseudoazurin structural genes are recognized by the FNR protein presumably present in $A$. faecalis and serve to enhance the transcription of these genes under anaerobic growth conditions.

E. coli possesses NADH-dependent NIR, which may account for the low NIR activity even in the untransformed $E$. coli cells (see Table 1); the expression of the $\operatorname{nir} B$ gene encoding the NIR is regulated not only by oxygen but also by nitrite (Cole, 1968; Jayaraman et al., 1987). The production of $E$. coli NIR was stimulated by two- to threefold by the addition of nitrite. Although several studies to reveal the nucleotide sequence responsible for the nitrite induction of the $\operatorname{nir} B$ gene of $E$. coli have been carried out, it has not yet been identified precisely (Jayaraman et al., 1988; Bell et al., 1990). Similar induction of the NIR production by nitrite was also found in A. faecalis (Kakutani et al., 1981a), suggesting the presence of a similar mechanism of induction by nitrite. However, comparison of the nucleotide sequences upstream of the nir gene from $E$. coli and nir $B$ gene from $A$. faecalis does not lead to identification of the homologous sequence possibly responsible for the nitrite induction. Further studies to reveal the mechanism for enhancing the expression of the nir and pseudoazurin genes are apparently required.

We thank K. Okamoto and H. Nagasawa (Department of Agricultural Chemistry, The University of Tokyo) for amino acid sequence determination of the NIR of $A$. faecalis.

\section{References}

Adman, E. T., Turley, S., Bramson, R., Petratos, K., Banner, D. V., TSernoglou, D., Beppu, T. \& Watanabe, H. (1989). A 2.0-Ä structure of the blue copper protein (cupredoxin) from Alcaligenes faecalis S-6. Journal of Biological Chemistry 264, 87-99.

AMBLER, R. P. (1977). The evolution of metalloenzymes, metalloproteins and related materials. In Proceedings of a Symposium of the Inorganic Biochemistry Discussion group of the Chemical Society, University of Sussex, pp. 100-118. Edited by G. S. Leigh. London: Symposium Press.

Bell, A. I., Cole, J. A. \& Busby, S. J. W. (1990). Molecular genetic analysis of an FNR-dependent anaerobically inducible Escherichia coli promoter. Molecular Microbiology 4, 1753-1763.

BRADFORD, M. M. (1976). A rapid and sensitive method for the quantitation of microgram quantities of protein utilizing the principle of protein-dye binding. Analytical Biochemistry 72, 248-254.

BURNETT, W. N. (1981). 'Western blotting': electrophoretic transfer of proteins from sodium dodecyl sulfate-polyacrylamide gels to unmodified nitrocellulose and radiographic detection with antibody and radioiodinated protein. Analytical Biochemistry 112, 195-203.

CoLe, J. A. (1968). Cytochrome c $c_{552}$ and nitrite reductase in Escherichia coli. Biochimica et Biophysica Acta 162, 356-368.

Cornelis, P., DignefFe, C. \& Willemot, K. (1982). Cloning and expression of a Bacillus coagulans amylase gene in Escherichia coli. Molecular and General Genetics 186, 507-511.

EiglmeIer, N., HoNorË, N., IUCHI, S., Lin, E. C. C. \& COLE, S. T. (1989). Molecular genetic analysis of FNR-dependent promoters. Molecular Microbiology 3, 869-878.

Fenderson, E. F., Kumar, S., Adman, E. T., Liu, M.-Y., Payne, W. J. \& Legall, J. (1991). Amino acid sequence of nitrite reductase: a copper protein from Achromobacter cycloclastes. Biochemistry 30, 7180-7185.

Godden, J. W., Turley, S., Teller, D. C., Adman, E. T., Liu, M.-Y., PaYNe, W. J. \& Legall, J. (1991). The 2.3 angstrom X-ray structure of nitrite reductase from Achromobacter cycloclastes. Science 253, $438-442$.

GrunsteIN, M. \& Hogness, D. S. (1975). Colony hybridization: a method for the isolation of cloned DNAs that contain a specific gene. Proceedings of the National Academy of Sciences of the United States of America 72, 248-254.

Hormel, S., Adman, E. T., Walsh, K. A., Beppu, T. \& Titani, K. (1986). The amino acid sequence of the blue copper protein of Alcaligenes faecalis. FEBS Letters 197, 301-304.

InouYe, S., Wang, S.-S., Sekizawa, J., Halegoua, S. \& Inouye, M. (1977). Amino acid sequence for the peptide extension on the prolipoprotein of the Escherichia coli outer membrane. Proceedings of the National Academy of Sciences of the United States of America 74, 1004-1008.

IKEMURA, H., TAKaGi, H. \& INOUYE, M. (1987). Requirement of prosequence for the production of active subtilisin $\mathrm{E}$ in Escherichia coli. Journal of Biological Chemistry 262, 7859-7864.

Jayaraman, P.-S., Peakman, T. C., Busby, S. J. W., Quincey, R. V. \& COLE, J. A. (1987). Location and sequence of the promoter of the gene for NADH-dependent nitrite reductase of Escherichia coli and its regulation by oxygen, the Fnr protein and nitrite. Journal of Molecular Biology 196, 781-788.

Jayaraman, P.-S., Gaston, K. L. Cole, J. A. \& Busby, S. J. W. (1988). The nirB promoter of Escherichia coli: location of nucleotide sequences essential for regulation by oxygen, the FNR protein and nitrite. Molecular Microbiology 2, 527-530.

KAKUTANI, T., BEPPU, T. \& ARIMA, K. (1981a). Regulation of nitrite 
reductase in the denitrifying bacterium Alcaligenes faecalis. (1981). Agricultural and Biological Chemistry 45, 23-28.

Kakutani, T., Watanabe, H., ARima, K. \& Beppu, T. (1981 b). Purification and properties of a copper-containing nitrite reductase from a denitrifying bacterium, Alcaligenes faecalis. Journal of Biochemistry, Tokyo 89, 453-461.

Kakutani, T., Watanabe, H., ARima, K. \& Beppu, T. (1981 c). A blue protein as an inactivating factor for nitrite reductase from Alcaligenes faecalis. Journal of Biochemistry, Tokyo 87, 463-472.

LAEMMLI, U. K. (1970). Cleavage of structural proteins during the assembly of the head of bacteriophage T4. Nature, London 227, 680-685.

LI, S.-F. \& Demoss, J. A. (1987). Promoter region of the nar operon of Escherichia coli: nucleotide sequence and transcription initiation signals. Journal of Bacteriology 187, 4614-4620.

Liu, M.-Y., Liu, M.-C., Payne, W. J. \& Legall, J. (1986). Properties and electron transfer specificity of copper proteins from the denitrifier Achromobacter cycloclastes. Journal of Bacteriology 166, 604-608.

Maniatis, T., Fritsch, E. F. \& Sambrook, J. (1982). Molecular Cloning: a Laboratory Manual. Cold Spring Harbor, NY: Cold Spring Harbor Laboratory.

Messing, J. (1983). New M13 vectors for cloning. Methods in Enzymology 101, 20-78.

Nishiyama, M., Suzuki, J., Ohnuki, T., Chang, H.-C., Horinouchi, S., Turley, S., Adman, E. T. \& Beppu, T. (1992). Site-directed mutagenesis of pseudoazurin from Alcaligenes faecalis S-6; Pro80Ala mutant exhibits marked increase in reduction potential. Protein Engineering 5, 177-184.

Petratos, K., Beppu, T., Banner, D. V. \& Tsernoglou, D. (1986). Preliminary characterization of crystals of nitrite reductase isolated from Alcaligenes faecalis strain S-6. Journal of Molecular Biology 190, 135.

Petratos, K., Banner, D. V., Beppu, T., Wilkinson, K. S. \& TSERNOGLOU, D. (1987). The crystal structure of pseudoazurin from Alcaligenes faecalis $\mathrm{S}-6$ determined at $2 \cdot 9 \AA$ resolution. FEBS Letters 218, 209-214.

SaIto, H. \& Miura, K. (1963). Preparation of transforming deoxyribonucleic acid by phenol treatment. Biochimica et Biophysica Acta 72, 619-629.

SANGer, F., Nicklen, S. \& Coulson, A. R. (1977). DNA sequencing with chain terminating inhibitors. Proceedings of the National Academy of Sciences of the United States of America 74, 5463-5467.

SCHEIN, C. H. \& NoteboRN, M. H. M. (1988). Formation of soluble recombinant proteins in Escherichia coli is favored by lower growth temperature. Bio/Technology 6, 291-294.

SOUTHERN, E. M. (1975). Detection of specific sequences among DNA fragments separated by agarose gel electrophoresis. Journal of Molecular Biology 98, 513-517.

SPIRo, S. \& GUEST, J. R. (1990). FNR and its role in oxygen-regulated gene expression in Escherichia coli. FEMS Microbiology Reviews 75, 399-428.

UNDEN, G. \& GUEST, J. R. (1985). Isolation and characterization of the Fnr protein, the transcriptional regulator of anaerobic electron transport in Escherichia coli. European Journal of Biochemistry 146, 193-199.

Yamamoto, K., Uozumi, T. \& Beppu, T. (1987). The blue copper protein gene of Alcaligenes faecalis S-6 directs secretion of blue copper protein from Escherichia coli cells. Journal of Bacteriology 169, 5648-5652.

YanisCh-PerRon, C., Vieira, J. \& Messing, J. (1985). Improved M13 phage cloning vectors and host strains: nucleotide sequence of the M13mp18 and pUC19 vectors. Gene 33, 103-119. 